\title{
THE TRANSFORMATION OF THE EGYPTIAN ISLAMISTS: GENUINE VALUE PLURALISM OR DEMOCRATIC WINDOW-DRESSING?
}

\author{
Ms. Gillian Kennedy
}

\begin{abstract}
During the 1990s, Egyptian society faced an upsurge of violent Islamist attacks by various jihadist inspired groups in which over a thousand people died. In the midst of increasing government suppression and public disgust at these terrorist attacks, other Islamist groups, such as the Muslim Brotherhood (MB) sought to re-orientate their dialogue and strategy towards a more pluralistic rhetoric. Concepts such as human rights, political pluralism and democracy were intermingled with the traditional Islamist narrative. The Egyptian experience, especially in relation to the transformation of the MB is worth discussing in order to address genuineness of this Islamist reorientation towards a new political agenda. Questions relating to positive democratic development and political pluralism need to be ascertained to assess whether the MB's transformation is mere democratic window-dressing brought about to gain power, or it is a realisation that a true alternative Egyptian hegemon must adapt to changing times amidst the face of a pluralistic populace. While the Egyptian experience is still being played out, there are indications that suggest the MB is in the midst of organisational change, yet with generational struggles constraining it. This paper shall utilise numerous political theories to produce a theoretical framework for examining power relations in the context of cultural currency and value norms in Egyptian society and how this can harness the ability to build a broad based consensual hegemon throughout Egypt. These emerging issues are replacing old power dynamics based on traditional hierarchical structures, and material capabilities such as military dominance and economic tribalism. Thus, central to this paper is highlighting the methodological framework necessary to explore the democratic credentials within the Egyptian Islamist counter-hegemonic movement.
\end{abstract}

Keywords: Egyptian Society, Gramsci, Muslim Brotherhood, Islamist, Democratic

\section{CULTURAL HEGEMONY: A NEW TYPOLOGY TO TEST POLITICAL ISLAM}

Finding a coherent typology for the different ideological positions within Egyptian Islamism is not something new on the research agenda. Indeed it is something that has increasingly been discussed across scholarly circles over the past decade, especially since 9/11. The binary labels of traditionalist/modernist are labels that blur the distinguishable differences across the spectrum of political Islamism because they frame the analysis around the restricting question of how compatible political Islamism is with democracy.

Whilst some try to answer this question with research analysis in the direction of Samuel Huntington's famous "clash of civilizations" thesis, aiming to explain the democratic deficit within political Islam as an inherent civilizational problematic, ${ }^{1}$ others have instead focused on

1 Samuel P. Huntington. The Clash of Civilizations and the Remaking of World Order (New York: Simon and Schuster, 1996) 
either the economic underdevelopment of Arab society as an explanation or indeed historic factors ${ }^{2}$ as the answer to this democratic deficit. These, however, are limited frameworks of analysis because 'democratization' as a term to test and define political Islam as an ideology does not work. Firstly, 'democratization' or indeed 'democracy' as a term of analysis is steeped in the Western liberal notion of democracy, which is underpinned with the values of the European Enlightenment, that is, the separation of church and state, a free market capitalist economy and the rights of the individual.

However with the experience of colonial rule and post-colonial state nationalism, political society in the Arab world has developed in a direction that lies outside of the Western liberal democratic modern tradition. On a global level, the problematic issue with the liberal democratization analytical approach is that, 'in the current research agenda there is a lack of a theory regarding the relationship between individual agents (like Islamists) and global ideological structures. There is a disconnection between the structural theories and the international system and the micro practices of the individual actors involved in the promotion of normative agenda in world politics. ${ }^{3}$

Whilst it is true that there is a gap in research analysis aiming to understand political Islamism as an alternative global ideology, the same conclusion can be drawn when examining political Islamism on a micro level.

This paper aims to use an alternative theoretical approach for assessing the various ideological strands of political Islamism in Egypt. Instead of formulating an assessment of the Egyptian Islamist movement through the prism of 'democratization', the objective here is to provide a critical account of the different ideological schools within Egyptian political Islamist thought, by putting them in their correct historic context and by highlighting the inherent contradictions in their programme for cultural hegemonic consent.

\section{LOOKING THROUGH THE METHODOLOGICAL LENS OF HEGEMONY}

To discuss cultural hegemony, we can't look anywhere else but within the writings of Antonio Gramsci, who developed this concept. Gramsci was an Italian Marxist who clarified his ideas whilst he was imprisoned by Mussolini's fascist government in the 1920s. He wrote more than thirty notebooks. They addressed subjects ranging from Italian nationalism to gender relations, though his most famous concept was his development of a cultural hegemonic theory. With this theory, Gramsci sought to explain why the inevitable socialist revolutions that were propagated by his own Italian Communist Party, had not occurred in Italy as they had in Russia in 1917. From this, he devised a strategy of cultural hegemony, which can be defined as:

\footnotetext{
'a situation whereby the subordinate group (in this case study the Islamists) secures hegemonic control of the State by obtaining consent from the masses as opposed to just dominating through purely coercive tactics i.e. ruling through the use of the armed forces, the police, and the judiciary. ${ }^{4}$

2 John Esposito, Islam and Democracy (New York: Oxford University Press, 1996)

3 Fiona Adamson, "Global Liberalism Versus Political Islam: Competing Ideological Frameworks in International Politics," International Studies Review, 7 (2004): 548.

4 References in the text to the Prison Notebooks are taken from Antonio Gramsci, Selections from the Prison Notebooks, edited and translated by Quintin Hoare and Geoffrey Nowell Smith (New York: International Publishers, 1971), hereafter referred to as $P N, 78$.
} 
The Gramscian model fits here for a number of reasons. Gramsci had lived in Italy at a period of (relatively) early capitalism combined with an authoritarian rule, and a relatively less developed civil society. For many countries today in the Arab world, this is distinctly familiar. His pertinence to Egypt may also be attributable to his exceptional sensitivity to cultural issues which is also extremely important in Egyptian society.

Using the Gramscian concept of cultural hegemony as a framework for assessing this political Islamist movement allows this research to circumnavigate the essentialism embedded in the limits of a Western liberal conception of democracy. Gramsci understood popular consent as cultural hegemony, not as a dominant ideology which simply shut out all alternative visions or political projects, but rather as a fragmentary hegemony, open to multiple interpretations and potentially supportive of different kinds of social visions and political projects. ${ }^{5}$

As a Marxist theorist, his work is useful as an alternative framework for analysing the Egyptian Islamist movement because it provides us with the conceptual tools for building an emancipatory cultural hegemonic project that does not reject Western capitalist modernity, but instead provides an alternative modernity based around cultural consent and a plurality of value systems. Modernity is seen as the development of industrial capitalist society. It is characterized alongside these materialist concerns with a value system based around the powers of science and reason, as well as a basic scepticism towards divinity. ${ }^{6}$ This value system is steeped in the ideals of the European Enlightenment philosophers; ${ }^{7}$ though too many to mention here, the main ideals of individual freedom, human reason and democracy are the nuts and bolts of this value system.

Yet what does this have to with the Egyptian Islamist movement? The typology of political Islamism cannot be examined without looking at modernity, because the worldviews that the political Islamists possess are both simultaneously a product of the historical process of modernity and a response to the Western liberal capitalist hegemonic project that went hand in hand with the experience of Egyptian society from colonialism to post colonial.

Since the various strands within political Islamism have emerged under this process, it is beneficial to construct a typology based around the various responses to modernity. The three schools of political Islamism can be defined by their response, whether that be rejection, reaction, or reconciliation. The notion of modernity in the form of Western capitalist hegemony cannot be sidelined; however the congruent value system with it is not a universal belief system to test the pluralist credentials of Egyptian intellectuals whose culture and history is defined by Islam, not secularism.

The underlying issue here is that the development of Western capitalism has resulted in a materialist capitalist structure but has not been accompanied by the universalisation of Western Enlightenment values in post colonial Egypt. This is because there is an inherent contradiction between the discourse of Western liberal democracy and the exploitative practices of the capitalist

5 Mark Rupert, Reading Gramsci in "an Era of Globalisation and Capitalism," Critical Review of International Social and Political Philosophy, 8 (2005) : 93-94.

6 Bruce B. Lawrence, Defenders of God: The Fundamentalist Revolt Against the Modern Age (London: Harper and Row, 1989)

7 The most prominent of the Enlightenment philosophical ideas in this context can be found in the writings of Montesquieu, Locke, Hobbes, and Kant. 
mode of production towards Arab societies as well as a negation of understanding towards Islamic cultural norms.

Egypt here acts as an example to point to an alternative value system that has evolved in three distinguishable intellectual directions within the political Islamist movement under the process of modernization over the past century.

Gramsci was an intellectual who viewed his role as an organic one in which his position is to relate to the populace and disseminate their pluralist message in a consensual manner. It is in his alternative intellectual discourse that a new mode of modernity and democracy can be found, which helps in examining Islamist intellectual discourse.

It is possible to categorize the worldviews of the three schools of political Islamism in Egypt by firstly, defining their framework for hegemonic rule that is their implementation of Shariah as a mode of governance. Secondly, by assessing their response to social and moral pressures brought about by modernity, such as gender issues and the rights of non-Muslims in an Islamic society. This is of particular importance to Egypt, since $10 \%$ of its populace are Coptic Christians.

One can classify these three Islamist schools here as a literalist school, a conservative school, and lastly a reformist school. The first is the literalist school, which can be exemplified by the later works of Sayyid Qutb, in particular his most influential book, Milestones, published in 1966.

The second school is the conservative Islamists, as personified by the Muslim Brotherhood under the General Guide, Hasan al-Hudaybi. Hudaybi was the author of the infamous refutation to Qutb's Milestones, with his Preachers, not Judges, in 1971. Hudaybi and other intellectuals in the Muslim Brotherhood have shifted their hegemonic discourse away from the literalist inspired jihadist approach, yet they remain controlled by an 'old guard' within the organisation that conceives of the world from a traditionalist conservative vantage point as exemplified by its modern spiritual leader, Yusuf al-Qaradawi and also by its more recent policy papers.

Lastly, the final school to be examined shall be the reformist school. This last approach has its roots in the early $20^{\text {th }}$ century reformers such as Ali Mohammad Afghani and Muhammad Abduh. Following the subsequent decline of this school during the Nasser and Sadat years, this approach can now be exemplified by intellectuals such as Hasan Hanafi and Adil Hussein.

\section{OVERCOMING OLD OBSTACLES: SHARIAH LAW}

One aspect of the cultural hegemonic project that Gramsci proposed is that if a political group based its mode of rule around a purely coercive and rigid doctrine it would result in becoming a mere bureaucratic device or in his own time, a 'dictatorship of the proletariat' The literalist worldview of Sayyid Qutb is based around a totalizing system of Islam alone, and anything outside of this, is steeped in jahilliya or ignorance. But if this is so, what exactly defines an ignorant society when looking at a mainly Muslim populated country such as $20^{\text {th }}$ century Egypt? According to Qutb, 'this ignorance is based on anything against God's sovereignty. It transfers to man one of the greatest attributes of God, namely sovereignty. ${ }^{8}$ The literalist worldview states that all those who do not live under God's sovereignty, i.e., do not live under Qutb's understanding of what a literalist Shariah ruled state is, are therefore living in ignorance. This hegemonic platform

8 Sayyid Qutb, Milestones (Indianapolis: Kazi Publications, 1983), 30. 
would later result in the Sayyid Qutb inspired jihadist groups in Egypt such as Al Jihad, which judged everyone except themselves to be living in a state of ignorance as unbelievers. Ultimately the best expression of this approach can be demonstrated by Adel Salam Faraj assassination of President Sadat for being a kafir in 1981.

In Qutb's understanding, God has overlooked nothing in the creation of the Shariah, and therefore according to him, 'we should not despair in the ability of the Shariah to govern modern society. If we consider this concept of God's sovereignty alone through the comparative prism of the Gramscian model, some serious theoretical shortcomings begin to surface. As was mentioned earlier, Gramsci sought to rediscover the means by which to construct a unified coalition consisting of diverse value systems. In doing this, Gramsci aimed to overcome the exclusionary limitations of Orthodox Marxism in his own context. Yet if we look at the literalist hegemonic model, which demands an implementation of God's sovereignty alone; whilst neglecting other value systems we can say that Qutb dismisses all alternative viewpoints and implicitly rejects political pluralism. Indeed, how can a strict adherence to a literalist interpretation of Shariah rule convince a multi-ethnic populace, with $10 \%$ Coptic Christians, to consent to its counterhegemonic programme, never mind different Islamic denonimations and secularists?

Qutb's condemnation of all who live outside God's sovereignty is a call for the rejection of Western modernity, but more worringly it castigates his own Egyptian society to the same world of ignorance for its un-Islamic behaviour from his perspective. What Qutb is demanding is not to Islamicize the state but in essence he wants to overthrow the whole state and civil society with it, by insisting on no human reasoning or dialogue with his contemporaries in the political system. This politics of rejection barely fulfils the Gramscian hegemonic programme with its call for a construction of ideology imbued with the character of the people; when clearly it is a reactionary response that was conceived in the context of isolation and alienation that dominated Qutb's historical context in 1960s Egypt.

In truth, whole examining both the conservative and reformist schools of political Islamism in Egypt, the abundance of legitimate inadequacies that the literalist school espoused can be clearly underlined. For example, the conservative school of Islamism in Egypt finds the notion of God's sovereignty alone as a benchmark for hegemonic rule decidingly. An example of how the conservative Islamists differ from this concept was outlined by Hasan al Hudaybi when he attacked the notion of hakimiyya as a distortion because it does not appear in either the Quran or the teachings of the Prophet. ${ }^{9}$

Additionally, the notion of God's sovereignty is not only a hinderance to gaining consent from the masses; but there are two other elements of this ideology that have had far reaching consequences for the generations that followed Qutb's death. In language not too dissimilar to the assumptive Orthodox Marxist stance that Gramsci refuted, Qutb proposed that while the material success of the regime tended to obscure its failings, in fact its creative period was over and that it actually stood on the edge of the abyss. ${ }^{10}$ There is an obvious affinity here with the presumptive stance of the Orthodox Marxists when they spoke about the inevitable fall of capitalism and the imminent ascent of the spontaneous revolt of the masses in favour of Marxism.

9 Yvonne Y. Haddad, "Sayyid Qutb: Ideologue of Islamic Revival," in J. Esposito, Voices of the Islamic Revolution (New York: Oxford University Press, 1983) 27.

${ }^{10} \mathrm{~S}$. Qutb, Milestones, 3-4. 
Reformist Islamists in Egypt have countered this assumption that once the literalist understanding of God's sovereignty is implemented, all of Egyptian society's woes shall miraculously disappear as purely naive. Indeed, Egyptian intellectuals such as Adil Hussain and Hassan Hanafi have argued that the application of Sharia under God's sovereignty has never historically guaranteed reforms that solve the problems society faces. ${ }^{11}$

The dilemma here is that the literalists unanimously maintain strict adherance to the Will of God, ensuring that any dissenting practice would not rupture the harmony established. But what sort of cultural hegemonic harmony can be established when the concerns of individuals are shelved in place of a unilateral disposition with the Will of God as the singular underlying factor? Indeed Gramsci's work specifically answered this conceptual dilemma when he focused on the reciprocal [emphasis added] relationship between the intellectuals of a movement and the people; and how it attained consensual unity among the masses. I would go as far as to say that Qutb's concept of hakimmiya, and the proceeding school of literalist heirs in Egypt post 1967, have produced a counter hegemonic project, that at its kernel is ultimately contradicatory. It concentrates on community harmony, but its persistance on unformity is akin to De Tocqueville's Tyranny of the Masses. ${ }^{12}$

With regard to the conservative school of thought, and in particular the MB's governmental platform, there is fear of the possibility of the imposition of Shariah law in the same way as expressed by the literalists, but this would be a mistake to judge them as the same. Similarities exist, but the implementation of Shariah is certainly different. The Brotherhood has been pressed again and again on how it envisions translating its stress on implementation of the Shariah into a practical political and legal program. Its leaders have given a variety of signals, both on what they wish to see implemented and how it might be done.

In their 2005 policy platform, they opted for reforming statements seeking to downplay differences with other social actors. The Brotherhood has spoken increasingly of an Islamic frame of reference and less of the implementation of Shariah law. Successive MB general guides have spoken on the need for ijtihad or human reasoning when speaking about the implementation of Shariah. In recent years, the Brotherhood has included an Islamic element in their governmental programme, but they have tended to emphases instead a long list of political reforms, which have been demanded by a broader spectrum of Egyptian political society. There is agreement within the movement with the idea that the people's elected representatives in parliament are generally the ultimate arbiter, no matter what political grouping they come from. Besides providing provisions for political reform in the 2005 platform, the MB also focused their statements on limiting the role of the state and promoting a greater role for civil society. The 2005 platform is indicative of how much the MB has shifted towards acceptance of a value pluralistic agenda, in promoting a variety of political perspectives instead of a purely Islamist doctrine.

However, it must be noted that their platform also glosses over differences within the movement concerning how much respect to pay to existing constitutional structures and how much of the Shariah code should be interpreted through the democratic process. The dilemma in this analysis is that the Brotherhood is currently speaking with several different voices, making it tricky to

${ }^{11}$ Abu Rabi. M. Ibrahim, Intellectual Origins of Islamic Resurgence in theMmodern Arab World (New York: State University of New York, 1996), 256.

12 Alexis De Tocqueville, Democracy in America (New York: Signet Classics, 1991) 
make concrete conclusions on its' decision making process. Yet there is no denying that there has been transformation in its' governmental platform over MB over the past 30 years. Long gone are the vague slogans of 'Islam is the solution.'

As was mentioned previously, the literalists in Egypt aimed at uniformity in their interpretation of Shariah. Both Qutb and Farag failed to address other value systems. Here the conservative school of political Islam differs again, especially if we look at how they have pursued value pluralism in both their hegemonic mode that is their implementation of Sharia but also in their response to rights of non-Muslims and gender issues. Their response to these issues can be described as reactionary at times and pragmatic at other times as opposed to the literalist response which can be characterized as utter rejection. How the MB conduct themselves with other political actors in Egyptian society demonstrates their transformation into a movement that respects value pluralism.

Gramsci had noted that for a movement to succeed in building a cultural hegemony, it needed to prepare the political consciousness of the masses so that people could inform the ideology of their own government, thereby ruling with the consent of multiple views. In his own time, Gramsci saw how this could work with the creation of Factory Councils in Italy; which would prepare the political consciousness of the masses. ${ }^{13}$ If cultural hegemony according to Gramsci is achieved through a grassroots process of education and consent like the Factory Councils; then the MB's success in capturing the professional syndicates in 1980s can surely work as parallel example. During the 1980s, they sought to re-establish themselves as a political actor, instead of a passive social movement which they had previously been. A new younger generation within the MB came of age at this time and aimed to penetrate the professional syndicates. They achieved successive victories throughout the eighties and nineties. These new younger Brothers became syndicate leaders, and helped to map out a new Egyptian identity, no longer subservient to the demands of 'westernization' that had little to offer the common man on the Arab Street. At the same time, they shattered the corrosive myth that Islamists were bent on recreating a medieval 'Arabian paradise. ${ }^{14}$

Essentially, these younger Brothers modernized their methods by providing practical initiatives that appealed to various value systems in Egyptian society. For example, in 1987, the MB successfully campaigned to win control of the doctors' union on a platform of health care reforms based on increasing state production of medicine and encouraging the government to retain subsidies for drugs. Their platform was so appealing that Coptic Christian doctors defied unprecedented demands by Pope Shenouda, the Coptic patriarch, to vote against the MB, which resulted in the Brothers winning control of the doctors' union. ${ }^{15}$

Additionally, they managed to capture the lawyers union which for years had been a predominantly secularist syndicate. Another significant moment for the MB, was in gaining victory of the pharmacists' syndicate. An estimated 30 percent of its members are Coptic Christians, yet in 1994 the MB won a landslide victory in the election. ${ }^{16}$ From the professional syndicates to electoral alliances, the MB have transformed their strategy over the last 30 years. In 1984, they formed their first political alliance with their old secular enemy, the Wafd Party. This

13 Anne Showstack Sassoon, Gramsci's Politics (London: Croom Helm Ltd, 1987), 193.

${ }_{14}$ Abdo, Geneive, Egypt and the Triumph of Islam (Oxford: Oxford University Press, 2000), 103.

${ }_{15}^{15}$ Geneive, Egypt and the Triumph of Islam, 100.

${ }^{16}$ Ibid., 101. 
election was a historic decision for the MB. Though their alliance was short lived, it nevertheless established them as a leading political player who had joined with the opposition to form a broad based coalition for reform. ${ }^{17}$ So does this mean that the conservative brothers have transformed themselves into a truly value pluralistic movement?

A example of concrete action from the Brotherhood to back up its democratisation rhetoric can be demonstrated in their participation with Kifaya movement in 2005.

This was a broad based coalition calling for political reforms, including an independent judiciary. ${ }^{18}$ Not only does this indicate that the MB are committed to essential elements of a democratic state such as an independent judiciary, it also highlights the movement's rapprochement with secular opposition forces in establishing a value pluralistic coalition. At this time, previous General Guide Akef outlined a response to calls that he wanted to impose a theocratic state by declaring that, "the Brotherhood seeks to create a civil party with an Islamic reference, established in harmony [emphasis added] with Article 2 that pertains to Sharia law of the constitution. ${ }^{19}$

Although the Brotherhood entered the political system in order to change it, it has ended up being changed by the system. Leaders who were elected to professional syndicates engaged in sustained dialogue and cooperation with members of other political groups. By the early 1990s, many within the Brotherhood were demanding internal reform. Some pushed for revising the Brotherhood's ideology, including its positions on party pluralism and women's rights. These divisions are a healthy development. All political movements have their hawks and doves, and the MB is no different. Internal dialogue shows that there are contesting views and that these multiple views can be consistent with a pluralist discourse. Internally, the conservative Islamists have changed in their implementation of Shariah, but they have also moderated their views towards non-Muslims and women.

Previous General Guides have made two points clear on the status of women and Coptic Christians in Egyptian governance. They have said that this is not a matter for the MB, but it is for Shariah law. Experts in Islamic law say that a state cannot have anyone as its head of state except a Muslim. It cannot have a woman as its head. This is a legal interpretation but MB leaders have made it clear that it is for their individual members to choose the conservative legal interpretation, but that it does not bind others. It is their position only. It does not bind all Egyptians on what they are to believe and they have stated that the ballot boxes decide that. Importantly, there has been a distinct shift in the conservative stance on gender issues since the 1970s. Previously, MB Sheikhs insisted that the principle of guardianship of a man over a woman was reserved for men in both the public and private sphere. Yet Sheikh Qaradawi in recent years has stated that the principle of guardianship relates to the private sphere only and that women are allowed to hold a variety of positions in parliament, including ministerial positions. This is indicative of a transformation towards gender issues, and also in distinguishing the conservatives from the literalists.

${ }^{17}$ Mona El-Gobashy, 'The Metamorphisis of the Egyptian Muslim Brotherhood,' International Journal of Middle Eastern Studies (2005) 37, 379.

${ }^{18}$ Michaelle Browers, 'The Egyptian movement for change: Intellectual antecedents and generational conflicts', Contemporary Islam ( 2007): 1, 72.

${ }^{19}$ M. Browers, 'The Egyptian movement for change: Intellectual antecedents and generational conflicts', 81. 
In contrast, if we look at some of the reformist attitudes to women and non- Muslims, as well as their hegemonic mode of Sharia governance, we can see another distinct strand within the Egyptian Islamist movement. Adil Hussain, a leading ideologue for the Labour Party in Egypt, insisted that women were allowed to hold the office of president, as could non-Muslims. Yet Hussain was a not a secularist. Indeed, he made two points clear: that Shariah must be the basis for a strong public morality, but that it must be applied in a way that is conducive with the 21 st century.

In his book, 'Towards a New Arab Thought, ' Hussain went on to note that a multiparty system that stressed value pluralism is indispensable to avoid stagnation in political thought and he linked this to political Islamism specifically. Like Hasan Hanafi, Adil Hussain spoke of himself as both an Islamist and a modernist. Significantly, intellectuals like Hussain have allied themselves with conservative MB members. Though for the reformists, political Islamism is reconciled with the pressures of modernity, such as gender issues and the rights of non-Muslims. Shariah, for them is seen not so much as providing the answers to problems or as an implicit mode of governance. Instead Shariah is seen as a moral force which will unite the population, but with emphasis on economic and social issues in Egypt.

Egypt's reformists have transformed themselves into a new type of Islamism. In many ways, they represent a third way Islamism. They make the use of community aspects that are prominent in an Islamic value system, such as social solidarity, whilst simultaneously offering a credible alternative to Egyptians of different value systems by concerning themselves first and foremost with social justice concerns.

In this, the reformists represent the key strand of Egyptian Islamism that has transformed itself into a value pluralistic ideology because it rests its moral outlook on traditional Islamic values of community solidarity, but is elastic enough to reconcile itself more cohesively with the pressures of modernity. Nevertheless, the reformist strand within Egyptian Islamism remains weak. It is clear that the conservative school remains the strongest strand within the movement.

\section{CONCLUSION}

In assessing the conservative's transformation, it is crucial to remember the divergent ideological strands that remain within the party. Often the older generation of the MB use hostile rhetoric against both Israel and the U.S, to placate the hardliners in the movement. In contrast, the younger generation of the MB who have a lot in common with reformist intellectuals like Hanafi and Hussain, are the generation of student activists and professional syndicate leaders who have come of age seeking dialogue with the U.S and Israel. They support the election victory of Hamas, but also argue for a democratic solution to the Israeli/Palestinian conflict, as opposed to pursuing the path of all out war. These internal divisions within the MB are a significant drawback to their democratic credentials. They have hampered the evolution of the MB's platform over its 80 year history. Divisions between liberal and conservative Islamists, are similar to other Islamic Parties throughout the world, such as the Islamic Party of Malaysia and the PJD of Morocco, who have also suffered from divisions between conservative and moderate approaches.

Like any political movement, factionalism is a problem that the MB needs to overcome so as to cement its position as a coherent political movement. 
The MB has come a long way since their early days of the 1930s, when parts of its organisation were involved in violent secret societies. In forming alliances with secular and leftist parties it has moderated its agenda. There is no doubt that there are staunchly conservative elements in the MB, their rhetoric is testament to that.

Throughout the 19th century, Christian political movements struggled to integrate their religious beliefs with a modern political system. After World War II, Pope XII issued a decree deeming democracy as a lawful practice. Soon after, the democratic Christian parties started to emerge. It ushered in a new era of Christian democracy across Europe. Similarly, Islamic movements such as the MB are now taking a pluralist approach to political participation. The conservative brothers are not the same as the literalists out to dominate the world with their dogmatic interpretation of Islam. They have transformed themselves into a value pluralist political movement which is seeking to enter the political process.

What is happening right now in Egypt is the opening up of a unique opportunity for the MB. Over the last 30 years, the MB have demonstrated their ability to listen to other political voices in Egypt. Their support with a diverse range of social actors in the present protests shows that they are seeking a free and democratic Egyptian political process, and not some Islamic theocracy.

Having laid the foundations for a Gramscian cultural hegemony, this paper can state with the utmost confidence that this analytical framework supports the argument presented here that the transformation of certain ideological strands into a genuine value pluralistic group is proven by their implementation of concepts that are embedded in the construction of a cultural hegemonic programme for governance. 


\section{SELECTED BIBLIOGRAPHY}

1. Abdo, Geneive. Egypt and the Triumph of Islam, Oxford: Oxford University Press, 2000.

2. Abu Rabi. M. Ibrahim, Intellectual Origins of Islamic Resurgence in the Modern Arab World, New York: State University of New York, 1996.

3. Adamson, Fiona. "Global Liberalism Versus Political Islam: Competing Ideological Frameworks in International Politics" International Studies Review, 7 (2004): 548.

4. Anne Showstack, Sassoon. Gramsci's Politics, London: Croom Helm Ltd, 1987.

5. Browers, Michaelle. "The Egyptian movement for change: Intellectual antecedents and generational conflicts', Contemporary Islam,( 2007): 1

6. El-Gobashy, Mona. 'The Metamorphisis of the Egyptian Muslim Brotherhood' International Journal of Middle Eastern Studies, (2005):37.

7. Esposito, John. Islam and Democracy, New York: Oxford University Press, 1996

8. Haddad, Yvonne Y. "Sayyid Qutb: ideologue of Islamic revival". In Esposito, J. Voices of the Islamic Revolution., (New York: Oxford University Press, 1983)

9. Huntington. Samuel P. The Clash of Civilizations and the Remaking of World Order, New York: Simon and Schuster, 1996.

10. Lawrence, Bruce B. Defenders of God: The Fundamentalist Revolt Against the Modern Age, London: Harper and Row, 1989.

11. Qutb, Sayyid. Milestones, Indianapolis: Kazi Publications, 1983.

12. Rupert, Mark. Reading Gramsci in an Era of Globalisation and Capitalism, Critical Review of International Social and Political Philosophy, 8 (2005).

13. Tocqueville, Alexis De. Democracy in America, New York: Signet Classics, 1991.

References in the text to the Prison Notebooks are taken from Antonio Gramsci, Selections from the Prison Notebooks, edited and translated by Quintin Hoare and Geoffrey Nowell Smith (New York: International Publishers, 1971) 